\title{
パーソナリティと家族関係が，主観的幸福感を介して 老年期における悲嘆と抑うつに及ぼす影響
}

\author{
$\bigcirc$ 橋本翔子・永井悪実 $\cdot$ 渡辺恭子 \\ (金城学院大学 人間生活学研究科) \\ キーワード : 老年期, 主観的幸福感, 抑うつ
}

The Effect of Personality and Family relation on

Grief and Depression in Senior through Subjective Well-being

Shoko HASHIMOTO, Ami NAGAI and Kyoko WATANABE

(Graduate School of Human Ecology, Kinjo Gakuin University)

Key Words: Senior,Subjective Well-being,Depression

\section{目 的}

近年，わが国においては著しい高齢化が進んでおり，2060 年には平均寿命が男性 84. 19 年，女性は 90.93 年になると見 込まれている。また，老年期は身体能力の低下や身近な人々 との死別といった経験から, 悲嘆や抑うつを感じやすい時期 とされている。このような状況の中で問題となってくるのは, 長期化した老年期を身体的だけでなく，心理的にもいかに健 康で満足して過ごせるかということだろう。近年，老年者を 対象とした研究においては，主観的幸福感が注目されてきた

（山下, 1992 など）。先行研究より，家族との交流が主観的幸 福感を介して, 抑うつに影響を与える(川久保, 2015)ことや,

パーソナリティ傾向が主観的幸福感に影響を与える（石 井, 1996) ことが明らかにされている。そこで本研究では,『個 人のパーソナリティと家族関係は，主観的幸福感を介して老 年期の悲嘆と抑うつに影響を与える』と仮説を立て，パーソ ナリティ，家族関係，主観的幸福感，悲嘆と抑うつがどのよ うな関係性を持つかを検討する。また, 本研究では老年者を対 象とするため, 抑うつだけでなく, 悲嘆についても考察する。 方 法

65 歳以上の老年者男女を対象に質問紙調査を行った。 (1)フェイスシート 属性と家族関係を問う 4 項目 (2)パーソナリティ Big Five 短縮版（並川ら, 2012）より『外 向性』と『神経症傾向』に関する項目

(3)主観的幸福感 モラールスケール（前田, 1979）

(4)悲嘆 Texas Revised Inventory of Grief-Present Scale

(Futterman ら, 2015) 筆者が日本語訳したもの。

(5)抑うつGDS 日本語短縮版（矢富, 1994）

なお，老年期にある被験者の負担と理解度を考慮し，(2)(4)は 本来 4 件法であるところ， 2 件法で評定してもらった。

$$
\text { 結 果 }
$$

共分散構造分析の結果から,『神経症傾向』から, 主観的幸福 感を介して『無力感』に有意なパスが認められた。加えて『明 るさ』『社交的』から『無力感』への有意な負のパスが認めら れた。また，主観的幸福感から悲嘆・抑うつに負のパスが認 められた。さらに, 家族との会話の快適さから『非受容』へ の正のパスが認められた。

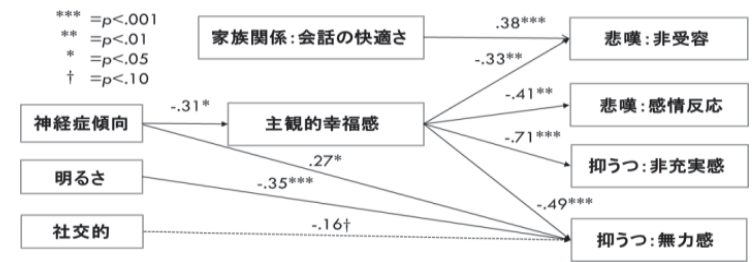

考 察

心配性で弱気になりやすい人は，自分の人生に満足感を見 出しにくく，その結果抑うつ的な無力感を高めると考えられ る。一方，明るく陽気な人や外交的で他者との交流を好む人 は，無力感を感じにくいことが示された。また，主観的幸福 感が老年期における悲嘆と抑うつに負の影響を及ぼしている ことが明らかになった。老年期において人生の満足度が高い 人は，人生に希望を持ち，他者の死を受け入れながら，より 充実した生活を送っていると言える。さらに, 家族との会話を 快いと感じている人ほど，他者の死を受け入れにくいという 結果から，家族と快い会話をしている人は，亡くなった他者 とも快い関わりをしてきた経験があり，そのためにその死を 受け入れることができないと考えられる。門田・寺崎 (2009) が指摘するように，『神経症傾向』が高い人ほど，行き詰まり や不満を多く体験してきたのならば，人生を統合していく老 年期において，その否定的出来事を誰かと共に振り返り，受 容していくことに大きな意味があるだろう。その“誰か”に は，従来家族が重要な役割を果たしてきた。しかし核家族化 が進んだ現代においては，専門職がその役割を担い，寄り添 っていくことが必要になるのではないかと推察される。

$$
\text { 引用文献 }
$$

Futterman, A., Holland, J. M., Brown, P. J., Thompson, L. W., \& Gallagher-Thompson, D. (2010) . Factorial validity of the Texas Revised Inventory of Grief-Present scale among bereaved older adults. Psychological Assessment, 22, No.3, 675-687.

門田昌子・寺崎 正治（2009）。パーソナリティ，日常的出 来事と主観的幸福感との関連 パーソナリティ研究，18, No. 1, $35-45$.

川久 保惊・小口 孝司（2015）。余暇における他者との交流 が主観的幸福感および抑うつに及ぼす影響 ストレス科学研 究, 30, 69-76.

山下一也・小林 祥泰 - 恒松 徳五郎 (1992) 。老年期独居生 活の抑うつ症状と主観的幸福感について一島根県隠岐島の 調査から一 日本老年医学会雑誌, 29, №. 3, 179-184. 前田 大作・浅野 仁・谷口 和江（1979）。老人の主観的幸福 感の研究—モラールスケールによる測定の試み一社会老年 医学, 11, 15-31.

並川努 - 谷 伊織 ・脇田 貴文・熊谷 龍一 - 中根 愛 - 野口 裕 之（2012）. Big Five 尺度短縮版の開発と信頼性と妥当性の 検討 心理学研究, 83, No. 2, 91-99.

矢富 直美 (1994)。 日本人における老人用うつスケール (GDS) 短縮版の因子構造と項目特性の検討 老年社会科学, 16 , 29-36. 